\title{
УДК: 631.527:631.529:635.621.3.
}

\section{РІВЕНЬ АДАПТИВНОГО ПОТЕНЦІАЛУ ЛІНІЙ КАБАЧКА ЗА ОЗНАКАМИ ПРОДУКТИВНОСТІ \\ С. І. КОНДРАТЕНКО, доктор сільськогосподарських наук, провідний науковий співробітник}

О. В. СЕРГІСНКО, кандидат сільськогосподарських наук,

О. П. САМОВОЛ, доктор сільськогосподарських наук, головний науковий співробітник

Р. В. КРУТЬКО, кандидат сільськогосподарських наук, старший науковий співробітник

Ю. М. ЛАНКАСТЕР, аспіранТ

Інститут овочівнцтва і баштанництва НААН Украӥни, E-mail: ovoch.iob@gmail.com

https://doi.org/10.31548/dopovidi2020.01.004

Анотація. За сучасних кліматичних умов сучасна селекція кабачка потребує створення високо адаптивного вихідного матеріалу. Для оцінки адаптивного потениіалу використовувалася 21 лінія кабачка, створена від зразків іноземної селекиії та такі показники: загальна і специфічна адаптивна здатність генотипу $\left.\left(3 A 3_{i} \text { i CA3 }\right)_{i}\right) ;$ відносна стабільність генотипу $\left(\mathrm{Sg}_{i}\right)$; коефіцієнт екологічноі пластичності $\left(b_{i}\right)$; селекиійна ијінність генотипу $\left(С Ц \Gamma_{i}\right)$. Протягом 2016-2018 pр. створено цінні лінії кабачка, які відзначилися стабільністю прояву ознак продуктивності. Найкращою була лінія ВЛ-90, у якої рівень прояву ознак "Загальна урожайність" $і$ "Продуктивність однієї рослини" був на рівні 63,35 m/2a i 3,11 кг/росл., відповідно. Виділено 3 лінії, ВЛ-91, ВЛ-92 і ЛК 17-44, які мали загальну урожайність понад $52 \mathrm{~m} / 2$ а і продуктивність однієї рослини понад 2,5 кг/росл. 3 а показниками адаптивності за двома вищевказаними ознаками лише одна лінія ВЛ90 і сорт-стандарт Чаклун мали низьку залежність від умов вирощування $\left(b_{i}<\right.$ 1). Виділилося 3 лінії, ВЛ-90, ЛК 17-7 і ВЛ-92, для яких прояв першої ознаки не залежав від умов вирощування. Ще 3 лінії за проявом двох досліджених ознак слід віднести до інтенсивного типу вирошування $\left(b_{i}>1\right)$ - ЛК 17-5, ЛК 17-44 i ЛК 1745. Створений вихідний матеріал має практичну ијінність для створення сортів $i$ гібридів $F_{l}$, як із високими екологічно-пластичними властивостями, так $i$ інтенсивного типу вирощування.

Ключові слова: кабачок, лінія, адаптивний потенціал, загальна урожайність, продуктивність однієї рослини, екологічна пластичність, селекиійна иінність генотипу

Актуальність. Кабачок (Cucurbita pepo L. var. giramontia Duch.) - одна 3 популярних i дуже цінних культур, належить до роду Cucurbita родини
Гарбузові (Cисиrbitaceae). Цінність кабачка зумовлена високими харчовими, дієтичними і лікарськими властивостями. $\mathrm{y}$ його плодах 
Кондратенко С. І., Сергієнко О. В., Самовол О. П., Крутько Р. В., Ланкастер Ю. М.

накопичується велика кількість легкозасвоюваних вуглеводів, каротину та різних груп вітамінів (C, $\mathrm{B}_{1}, \mathrm{~B}_{2}$, РР та ін.).

Генетичний потенціал кабачка має ще великі невикористані резерви для підвищення продуктивності та якості овочевої продукції. Для різних екологічних зон України важливу роль повинна відігравати селекція нових сортів i гетерозисних гібридів, які найбільш адекватно відповідають ринковим моделям. Селекція - це своєрідна технологія, яка починається від моделювання, підбору вихідних форм, схрещувань, вивчення комбінаційної здатності, сортовипробування і впровадження у виробництво. Останніми роками селекційна робота, що проводиться в Інституті овочівництва і баштанництва Національної академії аграрних наук України та іншими селекційними установами була скерована на вдосконалення сортименту кабачка, створення нових високопродуктивних та, залежно від зональної пріоритетності, високоадаптивних сортів і гібридів $\mathrm{F}_{1} 3$ високим вмістом біохімічних компонентів та стійкістю до стресових чинників умов вирощування [1, 2].

Аналіз останніх досліджень та публікацій. Урожайність сортів і гібридів $\mathrm{F}_{1}$ кабачка, створених в Інституті овочівництва і баштанництва НААН та мережею його дослідних станцій у середньому становить 4060 т/га [1, 3]. Для забезпечення необхідних

морфофізіологічних процесів росту i розвитку рослинам кабачка потрібна достатня кількість води [4]. У зв'язку із глобальними змінами клімату у бік посушливості та підвищення рівня весняно-літніх денних температур, створений у період більш помірного клімату (понад 10-15 років тому назад) вітчизняний сортовий i гібридний генофонд кабачка нажаль зазнав негативних тенженцій у прояві своїх апробаційних ознак i, як наслідок, знизив свою конкурентоздатність на ринку. Отже, проблема врахування кліматичних умов є важливим, як для географічного розміщення рослин кабачка, так i для вирощування повноцінної продукції.

3a

твердженням

А. В. Кільчевського і Л. В. Хотильової,
проблема $\quad$ визначення генотипу i середовища $\epsilon$ ключовим питанням адаптивної селекції сільськогосподарських видів рослин [5]. На основі проведених досліджень 3 випробування генотипів у різних природних середовищах, вищевказаними авторами був розроблений метод генетичного аналізу, який дозволяє виявити загальну i специфічну адаптивну здатність генотипів, їх стабільність і селекційну цінність за проявом кількісних ознак залежно від поставленого завдання. Даний метод широко використовується в Україні, в основному на зернових культурах [69]. Проте, інформації щодо його застосування у адаптивній селекції 
Кондратенко С. І., Сергієнко О. В., Самовол О. П., Крутько Р. В., Ланкастер Ю. М.

кабачка у літературних джерелах нами не зустрічалося.

Мета дослідження. Провести оцінку адаптивного потенціалу колекції ліній кабачка, створених на основі зразків іноземної селекції 3 метою відбору екологічно-стабільних лінійних генотипів за ознаками продуктивності.

Методи. У роботі було проведено трирічну (2016-2018 рр.) польову оцінку адаптивного потенціалу колекції ліній кабачка, створених методом добору i інцухтування (покоління $\mathrm{F}_{6} \mathrm{I}_{6}$ ) від зразків іноземної селекції за комплексом ознак, які визначають структуру урожайності. Колекцію іноземних зразків кабачка було надано селекційно-насінницькою компанією “A. L. Tozer Ltd” (Велика Британія) у рамках договору про проведення спільних генетик-селекційних досліджень 3 Інститутом овочівництва i баштанництва Національної академії аграрних наук. Дана колекція налічувала 21 лінію кабачка походженням з США, Великобританії, Іспанії та Італії. За стандарт було обрано вітчизняний сорт Чаклун (К-1768).

Польові дослідження проводились на експериментальній базі Інституту овочівництва і баштанництва НААН, розташованому в Лівобережному Лісостепу України в центральному середньо зволоженому районі Харківської області. Клімат помірний, середня кількість опадів за багаторічними даними складає 520 мм. У даній агрокліматичній зоні вегетаційний період для теплолюбних овочевих видів рослин, до яких належить і кабачок, починається 325 квітня за температури вище $10{ }^{\circ} \mathrm{C}$ i закінчується до 30 вересня.

У відкритому грунті досліди розміщувалися в овочевій сівозміні. Грунт дослідних ділянок представлений потужним малогумусовим чорноземом важкосуглинистим за механічним складом. Вміст гумусу в орному шарі $4,0-4,5 \%, \mathrm{P}_{2} \mathrm{O}_{5}-11-15 \mathrm{мг,} \mathrm{K}_{2} \mathrm{O}-8-10$ мг на 100 г грунту, pH 7,0-7,5. Грунт характеризується досить високою родючістю.

Погодні умови 2016-2018 pp. виявилися частково не сприятливими для росту і розвитку рослин кабачка. Під час появи сходів кабачка у II-III декаді травня спостерігалися різкі коливання температури повітря: середньодобова коливалась від 16,0$18,4{ }^{\circ} \mathrm{C}$, тоді як мінімальна становила 5,0-8,0 ${ }^{\circ} \mathrm{C}$. Максимальна температура повітря становила 27,0-28,0 ${ }^{\circ} \mathrm{C}$ за мінімальної температури грунту $1,5^{\circ} \mathrm{C}$. Опадів випало 111,5 мм у 2016 році, 26,0 мм у 2017 році та 17,5 мм у 2018 р. за багаторічної норми 55,5 мм.

У червні спостерігалися різкі коливання температури повітря. Середньодобова температура у 20162017 рр. становила 20,8-21,5 ${ }^{\circ} \mathrm{C}$, що на 0,6-1,3 ${ }^{\circ} \mathrm{C}$ вище за багаторічну, тоді як максимальна досягала $35-36{ }^{\circ} \mathrm{C}$. У 2018 році за середньодобової температури $19,2{ }^{\circ} \mathrm{C}$ у I декаді і $22,7^{\circ} \mathrm{C}$ у III декаді, максимальна температура становила 


\section{Кондратенко С. І., Сергієнко О. В., Самовол О. П., Крутько Р. В., Ланкастер Ю. М.}

$27,0-32,0{ }^{\circ} \mathrm{C}$, а мінімальна на рівні 3,0 ${ }^{\circ}$ C. У 2016-2017 pp. у червні випало 23,0-46,0 мм опадів за багаторічної норми 65,0 мм. У 2018 році опадів у цьому ж місяці випало 80,5 мм, що суттєво більше на 15,5 мм за багаторічну норму. Протягом 20162018 pp. у III декаді червня та I-II декаді липня під час формуванні зав'язі кабачка була жарка спекотна погода. Середньодобова температура повітря становила від $20,8{ }^{\circ} \mathrm{C}$ до $33,0{ }^{\circ} \mathrm{C}$ при багаторічній $21,6^{\circ} \mathrm{C}$.

За трирічний період польових досліджень опадів у липні випало 19,055,0 мм, за багаторічної норми - 73,3 мм. Мінімальна температура грунту становила $6,0-8,0{ }^{0} \mathrm{C}$, що призвело до різкого падіння здатності засвоювати рослинами поживні елементи. Ці негативні погодні умови вплинули на процес запліднення, зменшило урожайність і товарність зразків кабачка.

У цілому погодні умови 20162018 рр. виявилися несприйнятливими для росту і розвитку рослин кабачка, оскільки вони негативно вплинули на процес запліднення, зменшення урожайності і товарності плодів та призвели до ураження рослин борошнистою росою і інтенсивному заселенню попелицею.

Протягом 2016-2018 pp. за період вегетації рослин кабачка проведено 11-27 зборів плодів (з 1 липня до 30 вересня). Оцінку зразків колекції кабачка за комплексом цінних ознак було проведено за умов їх вирощування у відкритому грунті згідно методичних вказівок [10]. Статистичний обробіток експериментального матеріалу було проведено за методиками, викладеними у роботах $[5,11,12]$.

Для оцінки параметрів адаптивної здатності і екологічної стабільності лінійних генотипів використовували наступні показники: $X_{m e d}-$ середнє значення ознаки лінії або сортустандарту; $3 A 3_{i}$ i $C A 3_{i}$ - загальна i специфічна адаптивна здатність генотипу; $S g_{i}$ - відносна стабільність; $b_{i}$ - коефіцієнт екологічної пластичності, який визначає реакцію генотипу на варіювання умов середовища; $С Ц \Gamma_{i}-$ селекційна цінність генотипу [5].

Результати. У результаті проведених статистичних обчислень для подальшої селекційної роботи відібрано 9 перспективних ліній кабачка, які мали рівень прояву ознаки “Загальна урожайність” на рівні сортустандарту Чаклун у межах 44,73-63,35 т/га $\left(A_{m}=18,62\right.$ т/га) та значення показника “Селекційна цінність генотипу” (СЦГ $)$ на рівні 14,59-43,61 (табл. 1). Зокрема, це такі зразки як ЛК 17-5 (К-1918), ЛК 17-8 (К-1939), ЛК 1710 (К-1953), ВЛ-90 (К-1986), ВЛ-91 (К1994), ВЛ-92 (К-2005), ЛК 17-44 (К2019), ЛК 17-45 (К-2043), ЛК 17-48 (К2038). Найвищим показник “СЦГ, ” був у лінії ВЛ-90 (К-1986), у сортустандарту Чаклун (К-1768) даний він становив 39,94.

Реакцію лінійних зразків за проявом ознаки “Загальна урожайність" на умови вирощування 
Кондратенко С. І., Сергієнко О. В., Самовол О. П., Крутько Р. В., Ланкастер Ю. М.

визначали через загальну адаптивну здатність $\left(3 A 3_{i}\right)$, яка коливалася в межах від 1,85 до 20,48. Найвища загальна адаптивна здатність свідчить про властивість генотипу підтримувати характерну величину фенотипового прояву ознаки за різних умов. Найбільш вираженою вона була у зразку ВЛ-90 (К-1986) - 20,48, у сорту-стандарту аналогічний показник становив - 15,43 (табл. 1). На противагу сорту-стандарту всі 9 зразків кабачка мали більш високий показник специфічної адаптивної здатності $\left(C A 3_{i}\right)$, яка $є$ критерієм фенотипового прояву досліджуваної ознаки за специфічних агрокліматичних умов, де зразки вирощувалися протягом періоду досліджень (табл. 1). Серед досліджених зразків іноземного походження найвищим даний показник був у зразка ЛК 17-5 (К-1918) $\left(C A 3_{i}=1170,56\right)$, найменшим у зразку ЛК 17-8 (К-1939) $\left(C A 3_{i}=386,82\right)$. У сорту Чаклун даний показник становив 322,23.

\section{1. Адаптивна характеристика кращих ліній кабачка за ознакою} “Загальна урожайність", 2016-2018 рр.

\begin{tabular}{|c|c|c|c|c|c|c|c|}
\hline $\begin{array}{l}\text { № } \\
\text { 3/ח }\end{array}$ & Зразок & $\begin{array}{c}X_{\text {med }}, \\
\text { т/га }\end{array}$ & $b_{i}$ & $3 A 3_{\mathrm{i}}$ & $C A 3_{i}$ & $S g_{i}, \%$ & СЦГ \\
\hline 1. & сорт Чаклун (К-1768), st & 58,30 & 0,88 & 15,43 & 322,23 & 30,79 & 39,94 \\
\hline 2. & ЛК 17-5 (К-1918) & 49,59 & 1,98 & 6,72 & 1170,56 & 68,99 & 14,59 \\
\hline 3. & ЛК 17-8 (К-1939) & 44,73 & 1,14 & 1,85 & 386,82 & 43,97 & 24,61 \\
\hline 4. & ЛК 17-10 (К-1953) & 45,29 & 1,45 & 2,41 & 647,71 & 56,20 & 19,25 \\
\hline 5. & ВЛ-90 (К-1986) & 63,35 & 0,91 & 20,48 & 372,69 & 30,47 & 43,61 \\
\hline 6. & ВЛ-91 (К-1994) & 52,17 & 1,04 & 9,30 & 322,39 & 34,42 & 33,80 \\
\hline 7. & ВЛ-92 (К-2005) & 52,55 & 1,02 & 9,68 & 485,78 & 41,94 & 30,0 \\
\hline 8. & ЛК 17-44 (К-2019) & 56,46 & 1,62 & 13,59 & 870,01 & 52,24 & 26,29 \\
\hline 9. & ЛК 17-45 (К-2043) & 48,12 & 1,80 & 5,25 & 971,46 & 64,77 & 16,24 \\
\hline 10. & ЛК 17-48 (К-2038) & 50,94 & 1,18 & 8,07 & 417,28 & 40,10 & 30,04 \\
\hline & $X_{\min }$ & 44,73 & 0,88 & 1,85 & 322,23 & 30,47 & 14,59 \\
\hline & $X_{\max }$ & 63,35 & 1,98 & 20,48 & 1170,56 & 68,99 & 43,61 \\
\hline & $A_{m}=X_{\max }-X_{\min }$ & 18,62 & 1,10 & 18,63 & 848,33 & 38,52 & 29,02 \\
\hline & $\mathrm{HIP}_{0,05}$ & 7,12 & - & - & - & - & - \\
\hline
\end{tabular}

Відносна стабільність генотипу $\left(S g_{i}\right)$ дозволяє порівнювати результати досліджень проведених на різних видах овочевих рослин та їх окремими генотипами за різних умов вирощування [5]. По суті показник " $\mathrm{Sg}_{i}$ " $є$ аналогічним коефіцієнту варіації під час вивченні генотипу у різних середовищах. Для дослідженої вибірки мутантних зразків даний показник варіював у межах від 30,79\% до 68,99 \%. Найнижчу величину " $\mathrm{Sg}_{i}$ " мав зразок ВЛ-90 (К-1986), найбільшу - зразок ЛК 17-5 (К-1918) (табл. 1).

Особливості росту рослин залежно від покращення умов середовища можна визначити за величиною коефіцієнта регресії реакції генотипу на середовище (коефіцієнту екологічної пластичності) “ $b_{i}$ ”. Оптимальним 
Кондратенко С. І., Сергієнко О. В., Самовол О. П., Крутько Р. В., Ланкастер Ю. М.

вважається, коли $b_{i}=1$ за урожайності, вищій за популяційну середню. Якщо розглядати коефіцієнт “ $b_{i}$ ”, як показник екологічної пластичності, то генотип 3 $b_{i}=1$ має середню пластичність.

Згідно з одержаними результатами досліджена вибірка ліній кабачка розділилася на три групи, перша 3 яких мала значення коефіцієнту “ $b_{i}$ ” менше одиниці і до якої ввійшли сорт Чаклун (К-1768) і лінія ВЛ-90 (К-1986) 3 низькою реакцією на умови вирощування i впливу чинників навколишнього середовища. До другої групи увійшли 6 ліній, для яких значення коефіцієнту екологічної пластичності було більше одиниці $\left(b_{i}=\right.$ 1,14...1,98) - ЛК 17-5 (К-1918), ЛК 17-8 (К-1939), ЛК 17-10 (К-1953), ЛК 17-44 (К-2019), ЛК 17-45 (К-2043) і ЛК 17-48 (К-2038). Тобто, ці лінії належать до інтенсивного типу вирощування, оскільки продемонстрували високу чутливість до кліматичних умов та залежність від агрофону вирощування, відповідно. Виділено, також, 2 лінії, ВЛ-91 (К-1994) і ВЛ-92 (К-2005), які мали середню пластичність (значення коефіцієнту “ $b_{i}$ ” у межах одиниці).

Відібраний лінійний матеріал, який був оцінений за ознакою “'Загальна урожайність", був вивчений за іншою кількісною ознакою “Загальна продуктивність однієї рослини”, яка є структурним компонентом урожайності рослин кабачка. Дані щодо кращих лінійних зразків за показниками адаптивності за даною ознакою зведені в табл. 2. За узагальненими трьохрічними даними для всієї вибірки відібраних зразків кабачка розмах варіювання даної ознаки коливався в межах 2,36-3,11 кг/росл. $з$ амплітудою варіювання $A_{m}=$ 0,91 кг/росл. У сорту-стандарту Чаклун (К-1768) даний показник становив 2,88 кг/росл. Статистичні показники, які визначають адаптивні властивості сорту-стандарту такі: $b_{i}=0,91 ; 3 A 3_{i}=$ 0,$70 ; C A 3_{i}=0,78 ; S g_{i}=30,80 \% ; C Ц \Gamma_{i}=$ 2,02. Виділилася один лінійний зразок, ВЛ-90 (К-1986), який мав не тільки чітку тенденцію до зростання рівня прояву даної ознаки в межах похибки досліду сорту-стандарту, але й за більшістю статистичних показників, які визначають адаптивні властивості генотипів мав кращі показники $\left(X_{\text {med }}=\right.$ 3,11 кг/росл., $3 A 3_{i}=0,93 ; C A 3_{i}=0,90 ; S g_{i}$ $\left.=30,51 \% ; C Ц \Gamma_{i}=2,19\right)$.

За коефіцієнтом екологічної пластичності “ $b_{i}$ ” досліджена вибірка зразків кабачка за ознакою “Загальна продуктивність однієї рослини” мала дещо іншій розподіл на групи лінійних генотипів з різною реакцією на умови вирощування i чинників навколишнього середовища. До групи зразків кабачка з низькою реакцією на умови вирощування слід віднести сорт Чаклун (К-1768) і 4 лінії - ЛК 177 (К-1928), ВЛ-90 (К-1986), ВЛ-91 (К1994), ВЛ-92 (К-2005) $\left(b_{i}=0,06 . .0,87\right)$. До другої групи увійшли 3 лінії, для яких прояв даної ознаки залежав від зовнішніх чинників вирощування $\left(b_{i}>\right.$ 1) - ЛК 17-5 (К-1918), ЛК 17-44 (К2019), ЛК 17-45 (К-2043). Виділено, 
Кондратенко С. І., Сергієнко О. В., Самовол О. П., Крутько Р. В., Ланкастер Ю. М.

також, 2 лінії, ВЛ-91 (К-1994) і ЛК 17- пластичність (значення коефіцієнту “ $b_{i}$ ”, 48 (К-2038), які мали середню в межах одиниці).

2. Адаптивна характеристика кращих ліній кабачка за ознакою “Загальна продуктивність однісї рослини”, 2016-2018 рр.

\begin{tabular}{|c|c|c|c|c|c|c|c|}
\hline $\begin{array}{l}\text { № } \\
\text { 3/ח }\end{array}$ & Зразок & $\begin{array}{c}X_{\text {med }}, \\
\text { кг/росл. }\end{array}$ & $b_{i}$ & $3 A 3$ & $C A 3$ & $S g_{i} \%$ & СЦ $\Gamma_{i}$ \\
\hline 1. & сорт Чаклун, st (К-1768) & 2,88 & 0,91 & 0,70 & 0,78 & 30,80 & 2,02 \\
\hline 2. & ЛК 17-5 (К-1918) & 2,43 & 1,85 & 0,26 & 2,81 & 68,98 & 0,81 \\
\hline 3. & ЛК 17-7 (К-1928) & 2,47 & 0,06 & 0,29 & 1,17 & 43,78 & 1,42 \\
\hline 4. & ВЛ-90 (К-1986) & 3,11 & 0,77 & 0,93 & 0,90 & 30,51 & 2,19 \\
\hline 5. & ВЛ-91 (К-1994) & 2,56 & 0,97 & 0,38 & 0,78 & 34,45 & 1,70 \\
\hline 6. & ВЛ-92 (К-2005) & 2,57 & 0,87 & 0,40 & 1,17 & 42,04 & 1,53 \\
\hline 7. & ЛК 17-44 (К-2019) & 2,77 & 1,45 & 0,59 & 2,10 & 52,42 & 1,36 \\
\hline 8. & ЛК 17-45 (К-2043) & 2,36 & 1,68 & 0,19 & 2,33 & 64,74 & 0,88 \\
\hline 9. & ЛК 17-48 (К-2038) & 2,37 & 1,0 & 0,19 & 0,90 & 40,11 & 1,45 \\
\hline & $X_{\min }$ & 2,36 & 0,06 & 0,19 & 0,78 & 30,51 & 0,81 \\
\hline & $X_{\max }$ & 3,11 & 1,85 & 0,93 & 2,81 & 68,98 & 2,19 \\
\hline & $A_{m}=X_{\max }-X_{\min }$ & 0,75 & 1,79 & 0,74 & 2,03 & 38,47 & 1,38 \\
\hline & $\mathrm{HIP}_{0,05}$ & 0,34 & - & - & - & - & - \\
\hline
\end{tabular}

Висновки i перспективи. За результатами проведених селекційних досліджень протягом 2016-2018 рр. в агрокліматичній зоні Східного Лісостепу України створено цінний лінійний матеріал кабачка, похідний від зразків іноземного походження, який відзначився стабільністю прояву ознак "Загальна урожайність" і “Продуктивність однієї рослини”. Серед проаналізованих лінійних зразків домінуюче положення займає зразок ВЛ-90 (К-1986), який, порівнюючи зі стандартом, за двома дослідженими ознаками мав кращі показники рівня їх прояву (63,35 т/га i 3,11 кг/росл.) та кращі показники адаптивного потенціалу. Серед групи перспективних зразків слід також виділити 3 лінії - ВЛ-91 (К-1994), ВЛ92 (К-2005) і ЛК 17-44 (К-2019), які мали порівняно високі значення показника 'Селекційна цінність генотипу" за двома ознаками та відзначилися загальною урожайністю понад 52 т/га і продуктивністю однією рослини понад 2,5 кг/росл.

Аналізуючи зразки кабачка за показниками адаптивності слід зазначити, що за ознаками “Загальна урожайність" i “Продуктивність однієї рослини" лише одна лінія ВЛ-90 (К1986) i сорт-стандарт Чаклун (К-1768) мала низьку залежність від умов вирощування $\left(b_{i}<1\right)$. Виділено 2 лініі, ВЛ-91 (К-1994) і ВЛ-92 (К-2005), які мали середню пластичність $\left(b_{i} \approx 1\right)$ за ознакою “Загальна урожайність”. Інші 6 ліній належали до інтенсивного типу вирощування, оскільки їх урожайність залежала від агротехнічних умов вирощування і клімату $\left(b_{i}>1\right)$.

У дослідженого лінійного матеріалу адаптивний потенціал за 


\section{Кондратенко С. І., Сергіснко О. В., Самовол О. П., Крутько Р. В., Ланкастер Ю. М.}

проявом ознаки “Продуктивність однієї рослини” мав більшу диференціацію за реакцією на умови вирощування і клімату. Виділилося 3 лінійні зразки, ВЛ-90 (К-1986), ЛК 17 7 (К-1928) і ВЛ-92 (К-2005), для яких прояв даної ознак практично не залежав від умов вирощування та 2 лінії, ВЛ-91 (К-1994) і ЛК 17-48 (К2038), які мали середню пластичність $\left(b_{i} \approx 1\right)$. Ще три лінії за проявом двох

\section{Список використаних джерел}

1. Катаєва Т. Є. Новий середньостиглий сорт кабачка Консул. Вісник Полтавської державної аграрної академії. 2011. № 1. С. 69-71.

2. Пузік Л. М., Образцова 3. Г. Особливості формування врожайності кабачка залежно від кліматичних умов. Вісник Полтавської державної аграрної академії. 2012. № 1. C. 30-32.

3. Катаєва Т. Є., Борисенко Л. Д. Нові білоплідні кабачки-цукіні. Збірник наукових пращь [Інституту біоенергетичних культур $i$ иукрових буряків]. 2012. Вип. 15. С. 230-232.

4. Тихонова Т. Е., Горовая Т. К., Сергеев Г. В., Яровой Г. И. Селекция, технология выращивания и семеноводство кабачка и патисона: методические рекомендации. Харьков: ИОБ УААН, 2007. 22 с.

5. Кильчевский А. В., Хотылева Л. В. Метод оценки адаптивной способности и стабильности генотипов, дифференцирующей способности среды. Генетика. 1985. № 9, Т. 21. С. 1481-1490.

6. Гудзенко В. М., Васильківський С. П. Виведення сортів ячменю озимого адаптованих до сучасних умов Лісостепу України. Збірник наукових прачь Уманського НУС. 2017. Вип. 90(1). С. 63-70.

7. Демидов О. А., Васильківський С. П., Гудзенко В. М. Еколого-генетичні аспекти селекції ячменю озимого щодо підвищення його продуктивного та адаптивного потенціалу у Лісостепі України. Агроекологічний журнал. 2017. № 2. C. 194-200. досліджених ознак слід віднести до інтенсивного типу вирощування $\left(b_{i}>\right.$ 1) - ЛК 17-5 (К-1918), ЛК 17-44 (К2019) і ЛК 17-45 (К-2043).

Створений лінійний матеріал іноземного походження $\epsilon$ цінним вихідним матеріалом для проведення селекції кабачка, а саме для створення сортів i гібридів $F_{1}$, як 3 високим потенціалом адаптивності, так i інтенсивного типу вирощування.

8. Стариченко В. М., Голик Л. М., Ткачова Н. А. Оцінка адаптивної здатності та стабільності сортів і ліній в селекції пшениці озимої. Селекиія $i$ насінництво. 2014. Вип. 105. С. 77-84.

9. Васильківський С. П., Гудзенко В. М. Генетичні джерела підвищеного продуктивного та адаптивного потенціалу для селекції ячменю озимого у Центральному Лісостепу України. Вісник Уманського НУС. 2017. № 1. С. 90-94.

10. Андрієвська С. А., Непорожна Є. О., Тихонова Т. Є. Принципи і методи селекції овочевих рослин родини гарбузових. Кабачок. Патисон. Сучасні методи селекиії овочевих $i$ баштанних культур. Харків: ДП Харківська друкарня № 2, 2001. С. 188-213.

11. Литун П. П., Кириченко В. В., Петренкова В. П., Коломацкая В. П. Адаптивная селекція. Теория и практика на современном этапе. Харків: Інститут рослинництва ім. В.Я. Юрьева, 2007. 270 с.

12. Методика полевого опыта (с основами статистической обработки результатов исследований) / под ред. Б. А. Доспехов. Москва: Агропромиздат, 1985. $350 \mathrm{c}$.

\section{References}

1. Katayeva, T. Ye. (2011). Novyy seredn'ostyhlyy sort kabachka Konsul [New midseason courgette variety Consul]. Bulletin of Poltava State Agrarian Academy, 1, 69-71.

2. Puzik, L. M., Obraztsova, Z. G. (2012). Osoblyvosti formuvannya vrozhaynosti kabachka zalezhno vid klimatychnykh umov [Features of formation of courgette yield depending on climatic 
Кондратенко С. І., Сергіснко О. В., Самовол О. П., Крутько Р. В., Ланкастер Ю. М.

conditions]. Bulletin of Poltava State Agrarian Academy, 1, 30-32.

3. Kataeva, T. E., Borisenko, L. D. (2012). Novi biloplidni kabachky-tsukini [New white fetal courgette-zucchini]. Scientific papers of the Institute of Bioenergy Crops and Sugar Beet (2017): Collected articles, 15, 230-232.

4. Tikhonova, T. E., Gorovaya, T. K., Sergeev, G. V., Yarovoy, G. I. (2007). Selektsiya, tekhnologiya vyrashchivaniya i semenovodstvo kabachka i patisona: metodicheskiye rekomendatsii [Breeding, growth technology and seed production of courgette and scallop: guidelines]. Harkov: IOB UAAN, 22.

5. Kilchevsky, A. V., Khotyleva, L. V. (1985). Metod otsenki adaptivnoy sposobnosti i stabil'nosti genotipov, differentsiruyushchey sposobnosti sredy [Method for assessing adaptive ability and stability of genotypes, differentiating ability of the environment]. Genetics, 9 (21), 1481-1490.

6. Gudzenko, V. M., Vasylkivskiy, S. P. (2017). Vyvedennya sortiv yachmenyu ozymoho adaptovanykh do suchasnykh umov Lisostepu Ukrayiny [Derivation of winter barley varieties adapted to modern conditions of the ForestSteppe of Ukraine]. Collected Works of Uman National University of Horticulture, 90 (1), 6370.

7. Demidov, A. A., Vasylkivsky, S. P., Gudenko, V. M. (2017). Ekoloho-henetychni aspekty selektsiyi yachmenyu ozymoho shchodo pidvyshchennya yoho produktyvnoho ta adaptyvnoho potentsialu $\mathrm{u}$ Lisostepi Ukrayiny [Ecological-genetic aspects of winter barley breeding for enhancing its productive and adaptive potential in the Forest-Steppe of Ukraine]. Agro-ecological journal, 2, 194-200.

8. Starichenko, V. M., Golik, L. M., Tkachova, N. A. (2014). Otsinka adaptyvnoyi zdatnosti ta stabil'nosti sortiv i liniy v selektsiyi pshenytsi ozymoyi. Selektsiya i nasinnytstvo [Evaluation of adaptive capacity and stability of varieties and lines in winter wheat breeding. Breeding and seed production]. Breeding and seed production, 105, 77-84.

9. Vasylkivsky, S. P., Gudenko, V. M. (2017). Henetychni dzherela pidvyshchenoho produktyvnoho ta adaptyvnoho potentsialu dlya selektsiyi yachmenyu ozymoho u Tsentral'nomu Lisostepu Ukrayiny [Genetic sources of increased productive and adaptive potential for winter barley breeding in the Central Forest Steppe of Ukraine]. Collected Works of Uman National University of Horticulture, 90 (1), 90-94.

10. Andriyevs'ka, S. A., Neporozhna, Y. E.. O., Tykhonova, T. Ye. (2001). Pryntsypy i metody selektsiyi ovochevykh roslyn rodyny harbuzovykh. Kabachok. Patyson. Suchasni metody selektsiyi ovochevykh i bashtannykh kul'tur [Principles and methods of selection of vegetable plants of pumpkin family. Zucchini. Scallop. Modern methods of selection of vegetable and melons]. Kharkiv: DP Kharkivs'ka drukarnya № 2, 188-213.

11. Litun, P.P., Kirichenko, V.V., Petrenkova, V.P., Kolomatskaya, V.P. (2007). Adaptyvnaya selektsiya. Teoryya y praktyka na sovremennom étape [Adaptive breeding. Theory and practice at the present stage]. Kharkiv: Institute of Plant Growing. V.Ya. Yuryeva, 270.

12. Dospekhov, B. A. ed. (1985). Metodika polevogo opyta (s osnovami statisticheskoy obrabotki rezul'tatov issledovaniy) [The methodology of field experience (with the basics of statistical processing of research results)]. Moscow: Agropromizdat, 350.

\section{ADAPTIVE POTENTIAL LEVEL LINE OF COURGETTE BY TRAITS OF PRODUCTIVITY \\ S. I Kondratenko, O. V. Sergienko, O. P. Samovol, R. V. Krutko, Yu. M. Lancaster}

Abstract. In today's climate, modern courgette breeding requires the creation of highly adaptive starting material. To evaluate the adaptive potential, we used 21 courgette lines made from samples of foreign breeding and the following indicators: general and specific adaptive capacity of the genotype $\left(G A C_{i}\right.$ and $\left.S A C_{i}\right)$; relative 
Кондратенко С. І., Сергіснко О. В., Самовол О. П., Крутько Р. В., Ланкастер Ю. М.

genotype stability $\left(S g_{i}\right)$; environmental durability factor $\left(b_{i}\right)$; breeding value of the genotype $\left(B V G_{i}\right)$. During 2016-2018 valuable courgette lines were created that were characterized by the stability of the performance traits. The best sample was the VL90 line, in which the level of manifestation of the characteristics "Total yield" and "Productivity of one plant" was $63.35 \mathrm{t} / \mathrm{ha}$ and $3.11 \mathrm{~kg} /$ plant, respectively. There are 3 lines, VL-91,VL-92 and LC 17-44, which had a total yield of more than $52 \mathrm{t} / \mathrm{ha}$ and productivity of one plant over $2.5 \mathrm{~kg} /$ plant. According to the adaptability indicators for the two above mentioned features, only one VL-90 line and the Chaklun variety (standard) had a low dependence on growing conditions $\left(b_{i}<1\right)$. There were 3 lines, VL-90, LC 17-7 and VL-92, for which the manifestation of the first trait did not depend on the growing conditions. Three lines according to the manifestation of the two studied traits should be attributed to the intensive type of cultivation (bi> 1) - LK 175, LK 17-44 and LK 17-45. Created source material has practical value for creating varieties and hybrids of $F_{1}$, both with high ecological-plastic properties and intensive type of cultivation.

Key word: courgette, line, adaptive potential, total yield, productivity of one plant, ecological plasticity, breeding value of genotype 